\title{
THE POPULATION OF WHITE-BELLIED PLANTHOPPERS AND THEIR NATURAL ENEMIES: THE NEW PEST OF CORN IN LAMPUNG
}

\author{
I Gede Swibawa, Franciscus Xaverius Susilo, Agus Muhammad Hariri, \& Solikhin \\ ${ }^{1}$ Department of Plant Protection, Faculty of Agriculture, University of Lampung, Indonesia \\ Jl. Prof. Dr. Sumantri Brodjonegoro No. 1 Bandar Lampung 35145 \\ E-mail: igede.swibawa@fp.unila.ac.id
}

\begin{abstract}
The population of white-bellied planthoppers and their natural enemies: the new pest of corn in Lampung. The whitebellied planthoppers (Stenocranus pasificus), here in after referred to as WBP, as new exotic pests in Lampung have the potential to reduce corn production and threaten national food sovereignty. Therefore, population of the pest needs to be managed to prevent the outbreaks. However, there is still limited information on the bio-ecology of WBP. Thus, this research was conducted to: 1) study the population growth pattern of WBP on various corn cultivars and 2) document the natural enemies of WBP. This research was carried out from May to December 2017with a survey method on several corn fields in South Lampung and planting trial on an experimental field of Faculty of Agriculture, Universitas Lampung planted with 3 corn cultivars, i.e. Madura, P-27 and NK which were arranged in randomized complete block design with three replications. The results of the research showed: 1) there were two peaks of population density observed during plant growth. The peak of adult stage of macroptera population density occurred at 17 and 53 days after planting (dap), the highest number of leaves with oviposition mass was observed at 24 and 65 dap, while the peak of population density of nymph stage and adult stage of brachiptera occurred at 31 and 75 dap; 2) Natural enemies of WBP included 9 orders, classified as specialist predators of mirid bugs (Cyrtorhynus) and rove beetles (Paederus), and generalist predators of spiders (Araneae) and lady beetles (Coccinellidae). The population of specialist predators was fluctuated depending on WBP population, while the population of generalist predators was varied.
\end{abstract}

Key words: generalist predators, population growth pattern, specialist predators, Stenocranus pacificus

\begin{abstract}
ABSTRAK
Populasi wereng perut putih dan musuh alaminya: hama baru pertanaman jagung di Lampung. Munculnya wereng perut putih (WPP) sebagai hama baru di Lampung berpotensi menurunkan produksi jagung dan mengancam kedaulatan pangan nasional khususnya yang bersumber dari jagung, karena Lampung termasuk lima provinsi produsen jagung terbesar nasional. Oleh karena itu, hama WPP perlu mendapat penanganan yang segera sebelum populasinya meledak. Informasi dasar mengenai bioekologi WPP belum tersedia secara lengkap, karena hama ini merupakan hama baru di Lampung. Penelitian ini bertujuan untuk: 1) mempelajari pola perkembangan populasi WPP pada berbagai varietas jagung pertanaman jagung petani, dan, 2) mendokumentasikan jenis-jenis musuh alami yang berasosiasi dengan hama WPP. Penelitian ini dilakukan dengan metode survei pada beberapa lokasi pertanaman jagung di Lampung Selatan, dan percobaan penanaman 3 varietas jagung yaitu Madura, P-27 dan NK di kebun percobaan Fakultas Pertanian Unila di Natar. Penelitian berlangsung bulan Mei sampai dengan Desember 2017. Hasil penelitian menunjukkan: 1) Pola pertumbuhan kepadatan populasi WPP stadium dewasa macroptera, jumlah daun teroviposisi dan kepadatan stadium nimfa dan dewasa brachiptera pada semua varietas jagung mengikuti pertumbuhan tanaman. Ditemukan dua puncak kepadatan populasi selama pertumbuhan tanaman, puncak kepadatan populasi wereng dewasa macroptera terjadi ketika tanaman berumur 17 dan 53 hst, jumlah daun teroviposisi ketika tanaman berumur 24 dan 65 hst, stadium nimfa dan dewasa brachiptera ketika tanaman berumur 31 dan 75 hst. 2) Musuh alami yang berasosiasi dengan WPP meliputi 9 ordo, tergolong predator spesialis kepik mirid (Cyrtorhynus) dan kumbang rove (Paederus), serta predator generalis laba-laba (Araneae) dan kumbang kubah (Coccinellidae), populasi predator spesialis berdinamika mengikuti populasi WPP sedangkan populasi predator generalis bervariasi.
\end{abstract}

Kata kunci: pola perkembangan populasi, predator spesialis, predator generalisStenocranus pacificus 


\section{INTRODUCTION}

White-bellied planthoppers (WBP) are found as new pests capable of threatening corn production in Lampung Province which is one of the national corn production centers. Phenomenon of new pest reducing national production had occurred in 1985-1986 which was the brown-stem planthoppers attacking and damaging about 75,000 ha of rice plantations in Central Java (Untung, 2001). Therefore, WBP in corn known as new pests need to get serious attention so that the population will not reach outbreak densities leading to damage to corn crops in Lampung Province.

One factor that causes pest populations outbreaks which finally damage crops is intensification of crop cultivation (Nicholls \& Altieri, 2007). The use of superior cultivars susceptible to pests and the excess nitrogen fertilizer application can cause plants to be susceptible to the pests attack because they contain high nutrients for pests so that they can spur the growth of pest populations (Staley et al., 2010; Alagar et al., 2007; Visarto et al., 2001). Excessive application of chemical pesticides often kills natural enemies of the pests, thereby encouraging the outbreak of pest populations (Beers et al., 2016).

According to Sumardiyono, (2016, personal communication), corn farmers in Lampung province reported an attack of planthoppers on corn plants in 2016. The preliminary survey to confirm the report showed that the planthoppers attacking the corn plants were different from Peregrinus, planthoppers commonly known as corn planthoppers. The planthoppers attacking the corn plants as reported by the farmer have specific trait of white waxy layer on the ventral abdomen. Due to its specific characteristic, then the planthopper is named white-belly planthopper (Stenocranus pacificus Kirkaldy) (Hemiptera: Delphacidae) (Susilo et al., 2017).

WBP attacks significantly reduce corn production. According to corn farmer in Natar, South Lampung, Suyono (2017, personal communication), WBP's attack in the dry season of 2017 resulted in severe damage reducing corn production to $52.2 \%$ when compared to the production of corn plants slightly attacked by WBP in the rainy season. Corn plants attacked by WBP produce small cob and light seeds which are fragile and easily broken when knocked out by threshing machines.

Planthoppers that have been reported to attack corn crops in Indonesia before 2017 are different from WBP. Surtikanti (2011) reported that the planthoppers attacking corn was Peregrinus maidis which was also mentioned in Kalshoven (1981). In other countries such as Brazil, planthoppers associated with corn crops include Caenodelphax teapae, P. maidis, Pyrophagus tigrinus, and Toya propinqua. Those planthoppers are the vectors of Mal de Rio Cuarto virus, a virus included in plant quarantine disturbing organisms (OPTK) which are prevented from entering and spreading in Brazil (de Oliveira et al., 2013). Almost all planthoppers attacking corn plants become vectors of viruses that cause diseases of corn plants (Naulth \& Amar, 1989).

In Indonesia, Nelly et al. (2017) reported that corn crops in West Sumatra were attacked by S. pacificus (Hemiptera: Delphacidae). The planthoppers attack was widespread in all districts surveyed. The level of $S$. pacificus attacks on vegetative phase of plants is higher than on the generative phase. The attacks of corn planthoppers were also reported by Susilo et al. (2017) in Lampung. S. pacificus, corn planthoppers from the Delphacidae family, attacking corn crops was also reported by Dupo \& Barrion (2009).

The WBP attacks on corn crops in Lampung began to receive serious attention after reports from Susilo et al. (2017). Based on morphological characteristics and population outbreak, WBP is thought to be an exotic plant in Lampung. This paper outlines the results of research on the population growth and natural enemies of WBP in several cultivars of corn.

\section{MATERIALS AND METHODS}

Research Site. The survey of WBP was carried out on several corn fields which included the Experimental Field of Faculty of Agriculture, University of Lampung and the corn fields owned by farmers in Natar, South Lampung. In addition to the Survey, observations were also made on experimental plots planted with different cultivars of corn. The research was conducted from March to October 2017.

Survey on the Corn Fields of the Farmers. Corn fields set to conduct survey were mostly owned by farmers located in Sidodadi, Natar District, South Lampung. There were 3 corn fields set as the object of the survey. The first one (field 1) is located in the experimental field of Faculty of Agriculture, Universitas Lampung, in the village of Muara Putih with a geographic position of $5^{\circ} 15^{\prime} 15.1782^{\prime \prime} \mathrm{S}$ and $105^{\circ} 13^{\prime} 57.3096^{\prime \prime} \mathrm{E}$. The second and third ones (field 2 and 3 ) were fields owned by the farmers located in Sidodadi Village, with geographical positions of $5^{\circ} 15^{\prime} 39.9024^{\prime \prime} \mathrm{S}$ and $105^{\circ} 14^{\prime} 55.1488^{\prime \prime} \mathrm{E}$. The area of field 1 and 2 are 0.5 ha each planted with corn cv. P-27 and the area of field 3 is 0.3 ha planted with corn cv. B54-BIOCID. 
In the survey of WBP, the sample unit was one corn plant with a sample size of 25 plants in each of the observed fields. A total of 5 rows of plants were chosen randomly using the Excell program. The selected crop rows were labeled and five samples were selected in each row.

Observation on the Experimental Plots: On a $40 \times$ $33 \mathrm{~m}$ field, 9 plots of experimental units measuring $10 \times$ $12 \mathrm{~m}$ of each were made. Three corn cultivars, i.e. Madura (local cultivar), P-27 (hybrid), and NK were planted in each experimental plot. The plots were arranged in a completely randomized design. In each plot of the experiment units, five sample points were selected systematically following the diagonal line, in which 4 sample points were located in the plot corners and the other was in the middle. In each sample point, 4 plants were determined to be observed, so that there were 20 sample plants in each plot. Observations were made every week since the plants were 10 days after planting (dap), until the plants were ready to be harvested (87 dap).

Calculation of WBP Population. WBP population in each plant was calculated. Calculations were performed on a leaf in which the highest WBP population was found. WBP populations are divided into two categories, i.e. the population of winged WBP (macroptera) and wingless WBP (stages of nymphs and brachiptera). WBP population was calculated directly (direct counting) using a hand-tally counter. In addition, all leaves of the sample plant and the leaves infested with WBP eggs, leaves showing the existence of a white waxy mass (oviposition mass) along the leaf vein, were also counted. Of all leaves with oviposition mass, one leaf showing the longest mass sequence was chosen and the percentage of the wax cover was estimated.

\section{Calculation of WBP Natural Enemies Population.} The population of WBP natural enemies (especially predators) in each sample plant was also observed. The natural enemy groups observed were spiders (Araneae), net-winged insects (Neuroptera), lady beetles (Coleoptera: Coccinellidae, both in the larval and imago phases), mirid bugs of Cyrtorrhinus (Hemiptera: Miridae), and other predators (if any). The calculation of natural enemy populations was also carried out directly (direct counting) using hand-tally counters.

\section{RESULTS AND DISCUSSION}

WBP Population in Farmers' Corn Fields. Observations on the field 1 (the experimental field of Faculty of Agriculture, University of Lampung) showed that WBP population density increased with the increasing age of corn plants. It appears that 30 days after planting (dap), the WBP population was $1.28 \pm$ 0.29 individuals per leaf, then increased to $34.36 \pm 7.38$ individuals per leaf, and increased to $81.28 \pm 23.13$ individuals per leaf at 70 dap (Figure 1).

Observations on the field 1 and 2 showed the dynamics of the WBP population within 3 months of observation. On the field 2, WBP population in April was about 94 individuals per leaf increasing to 200 individuals per leaf in May and decreasing to only 4 individuals per leaf in June. The phenomenon of the

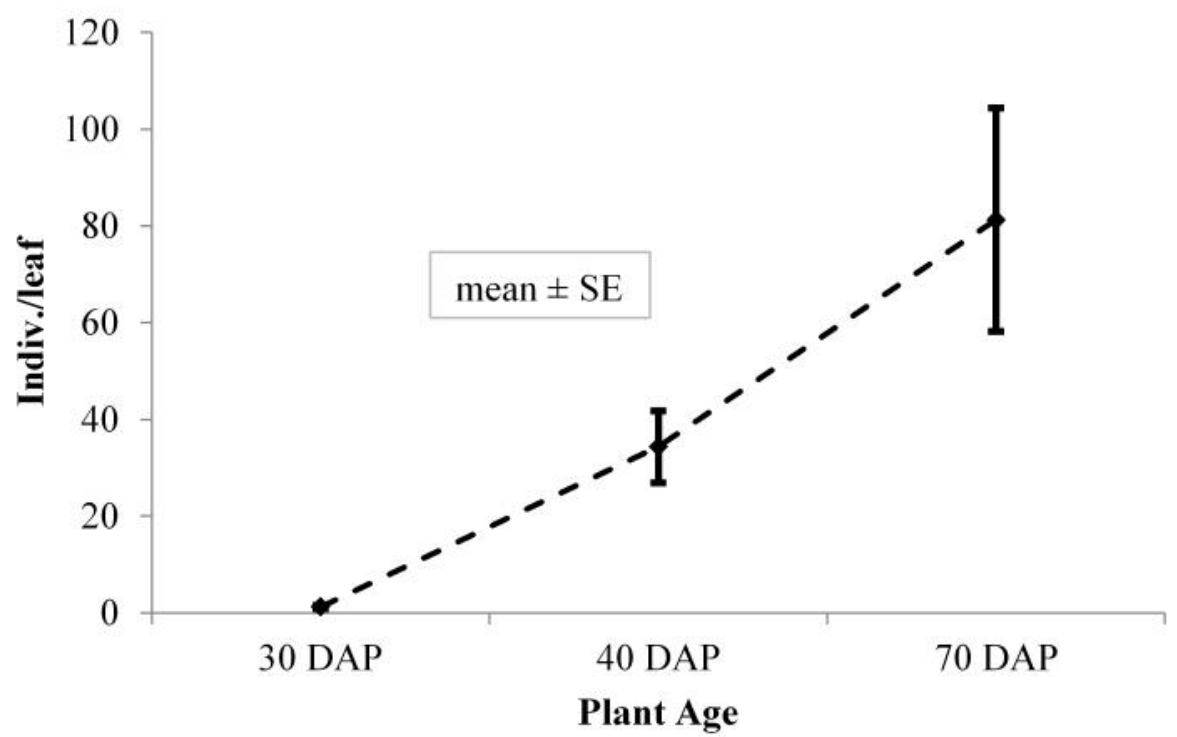

Figure 1. Population density of WBP on corn plants in experimental field of Faculty of Agriculture, University of Lampung, Natar, South Lampung. 
decline in the WBP population from April to June also occurred on the field 3 in which the WBP population in April was high reaching around 200 individuals per leaf and then dropped to around 75 individuals per leaf in May and declined to about 20 individuals per leaf in June (Figure 2). The fluctuations in WBP population density are estimated to be influenced by the age of corn plants. On the field 1 , the planthoppers population continued to increase with the increasing of the age of the plant up to 70 days (Figure 1). The results of this study are different from those of Nelly et al. (2017) mentioning that the WBP population in vegetative phase plants was higher than the population in generative phase plants.

The composition of the stages of the WBP population in every month in the field 2 is presented in
Figure 3. In April and May the proportion of the stages in the WBP population was dominated by the nymph and the short-winged adult (brachiptera) stage reaching 97\% of all WBP individuals. Conversely, in June the proportion of nymph and brachiptera stage in the WBP population became $18 \%$ lower than the winged adult stage (macroptera) reaching $82 \%$. From these data, it appears that the nymphs formed in April and May have grown to become imago which are ready to migrate in June, so the composition of the stage of the WBP population in June is dominated by winged imago.

The phenomenon of changes in stages composition in the WBP population from April to June also occurred on the field 3 as shown in Figure 3. In April, the proportion of nymph and adult brachiptera reached $96 \%$ and that of adult macroptera was only
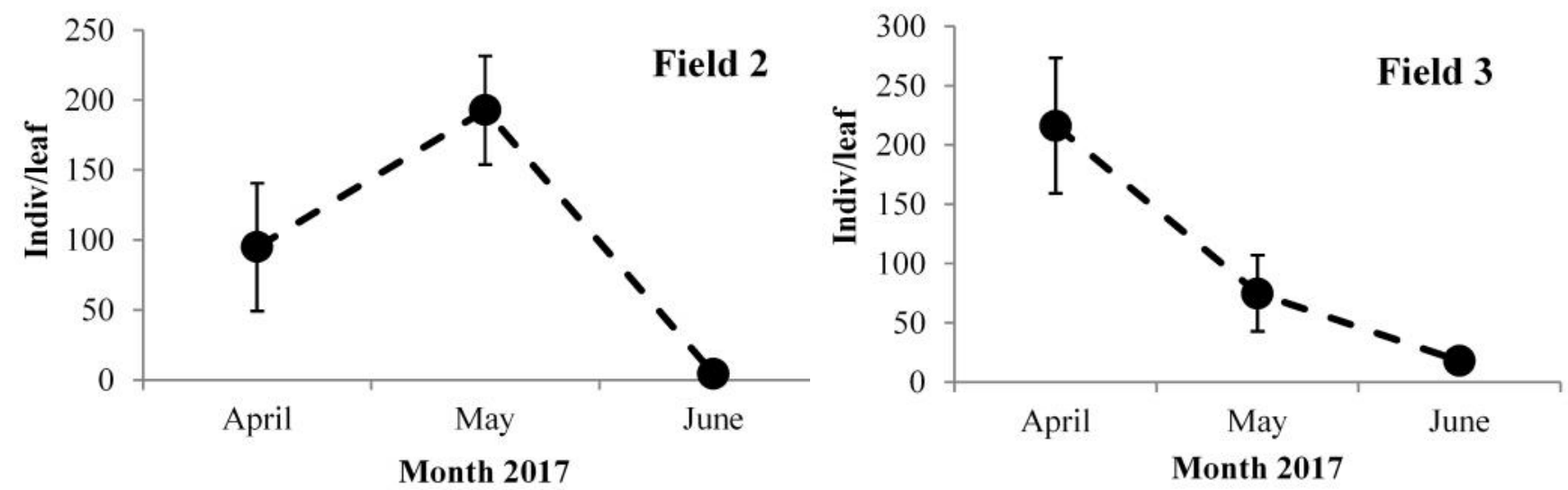

Figure 2. Population dynamics of WBP from April to June on two fields observed.
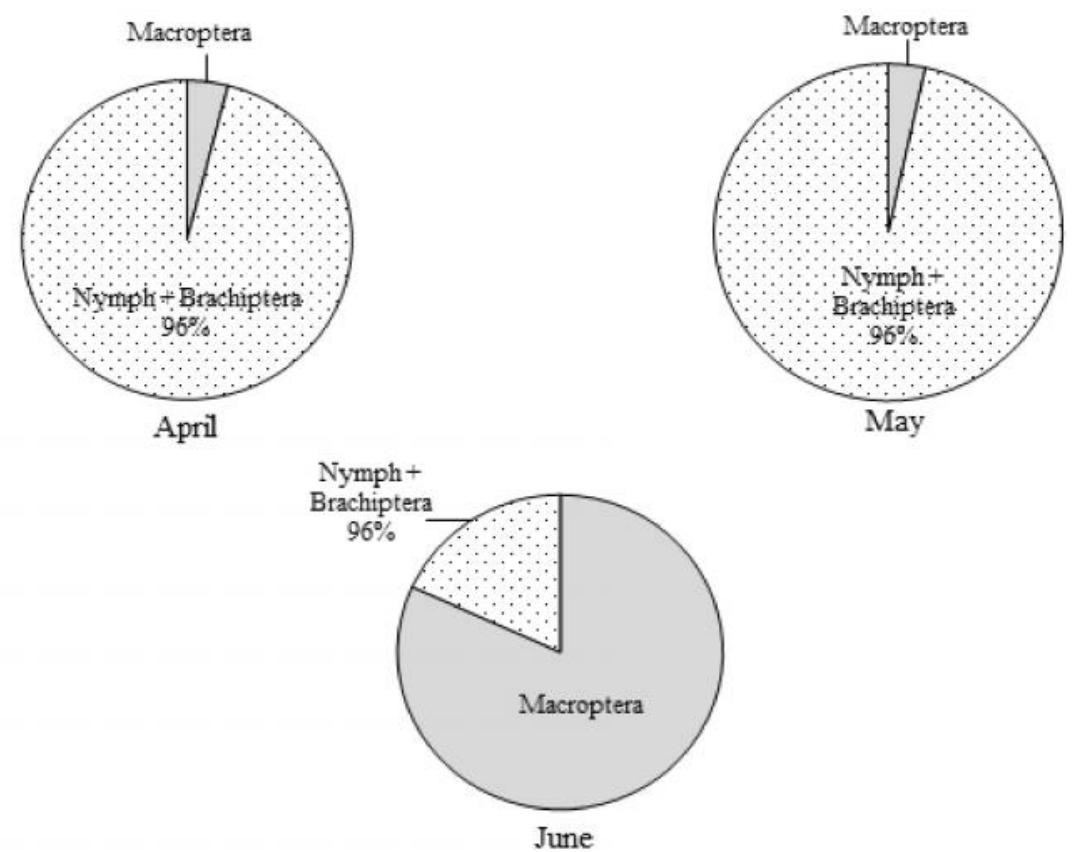

Figure 3. Composition of nympha stage, brachiptera, and adult winged white-bellied planthoppers in the field 2. 
4\%. In May, there was a change in stages composition in the WBP population, i.e. the adult macroptera stage was $37 \%$ and the stage of nymph and brachiptera was $67 \%$. In June, the macroptera stage predominated reaching $92 \%$ and the stage of nymph and brachiptera was $8 \%$.

In Figure 2 it appears that the WBP population density in June was low ( $<20$ individuals per leaf), meanwhile Figure 3 and 4 show that in June the WBP population was dominated by winged adults. This phenomenon is reasonable, because corn plants were old so that their nutrients had been reduced so they could not meet WBP's needs. As a result, these planthoppers must migrate to young plants with high nutrition. To be able to move to other plants, WBP must develop wings to fly to a farther location (Syobu et al., 2002; Dyck et al., 1979).

The observations of WBP on farmers' corn fields showed that population density increased with the increasing of plant age and a sharp increase occurred since 30 dap until 70 dap in field 1 (Figure 1). Observation on field 1 was carried out in March 2017 in which the WBP population was high. Observations from April to June conducted in field 2 and 3 showed low population density of WBP in June (Figure 2). The results of this study have not been able to explain the causes of the decline in population density that occurred from May to June. At the peak of population density in April and May, WBP was dominated by adult brachiptera and nymph stage reaching $96 \%$. In June, the WBP population density was dominated by full winged adults reaching 82-92\% of all individuals in the WBP population (Figures 3 and 4). In April, WBP which were still in the nymph and brachiptera stages did not have wings to fly to migrate. This may be because corn plants were still in a young growing phase and they contain optimum nutrients for WBP, so there is no need to migrate to find new food sources. Meanwhile, in June, the plants no longer contained optimum nutrients, so that WBP had to migrate farther by flying using wings. Due to that condition, WBP started forming wings in June.

WBP Population in the Experimental Plots. WBP population on corn plants in the field of experimental plots consisted of winged planthoppers (macroptera) and short-winged planthoppers including young planthoppers (nymphs) and short-winged adult planthoppers (brachiptera). WBP population density was fluctuating during the corn plants growth. 10 days after planting, WBP population of macroptera, winged adult planthoppers, was high reaching 15 individuals per plant, then decreased as the plant aged. The WBP population of macroptera became very low when the plant was ready to be harvested ( 87 dap) i.e. 0 individuals per plant. Patterns of fluctuations in population density of WBP macroptera on three corn cultivars are similar (Figure 5).
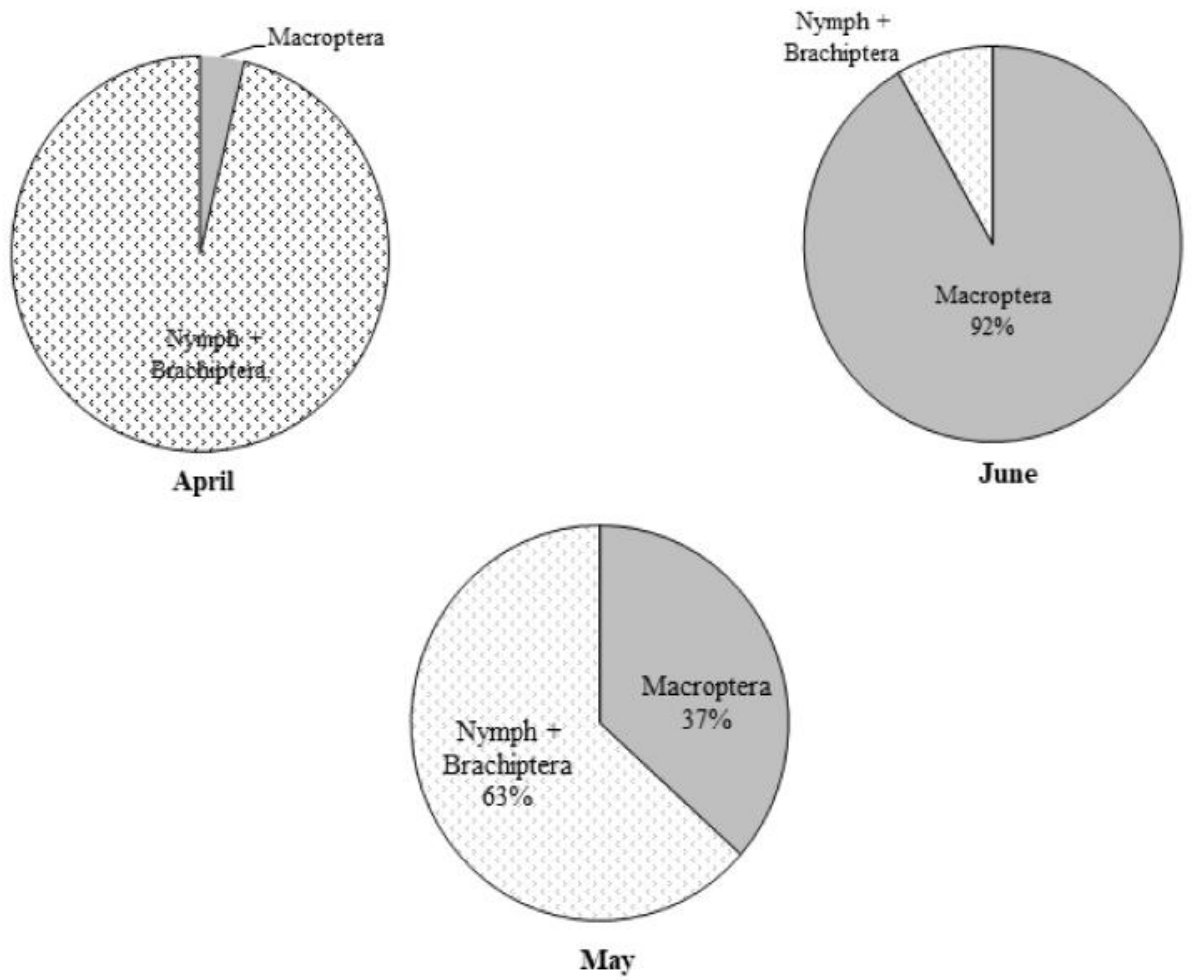

Figure 4. Composition of nympha stage, brachiptera, and adult winged white-bellied planthoppers in the field 3. 
The fluctuations pattern in the WBP population density of the nymph and adult brachiptera stage is different from that of the full winged WBP adult stage. Population density of WBP brachiptera and nymph stage was high at 31 days after planting. In older plants, the population density of WBP brachiptera and nymph stage decreased steadily until the plants were ready to be harvested (87 dap) (Figure 5). The fluctuations pattern in the WBP population density of brachiptera and nymph stage on the three cultivars was observed similar, and the population density tended to be not different.

WBP has the behavior of laying a white-waxcovered egg along the leaf vein. The number of leaves infested with eggs (oviposition mass) fluctuated during plant growth. At 10 dap, the number of leaves with oviposition mass was still low, then increased and reached the highest value at 20-30 dap, then began to decline at 50 dap, increased again and reached the lowest value at 87 dap. The fluctuations pattern in the number of leaves with oviposition mass among corn cultivars was almost the same, but at the peak of egg infestation at 30 dap, the number of leaves with oviposition mass on cv. NK and P-27 was lower than that on cv. Madura
(Figure 5). The number of leaves with oviposition mass can indicate WBP population density.

In the experimental plots, the highest population density of WBP was observed at 17 dap. However, the population was only about 12 individuals per plant. This low population density consisted of foundatrix population, i.e. newly winged insects migrating from another place to new plants (Figure 5). The foundatrix WBP then placed the egg covered with white wax on the leaves one week later so that the highest number of leaves with oviposition mass was observed at 24 dap (Figure 5). These eggs then hatched into nymphs one week later, so the peak of population density of nymph and WBP brachiptera occurred at 31 dap (Figure 5). Susilo et al. (2017) reported that the WBP population in corn plants 40 dap was dominated by nymph and short-winged adults stages, the peak of population occurred at 70 dap and it caused hopperburn on plants at 88 dap, while Nelly et al. (2017) reported that the WBP population in corn plants was higher in vegetative phase than in generative phase.

The population density of nymph and winged WBP and the number of leaves with oviposition mass
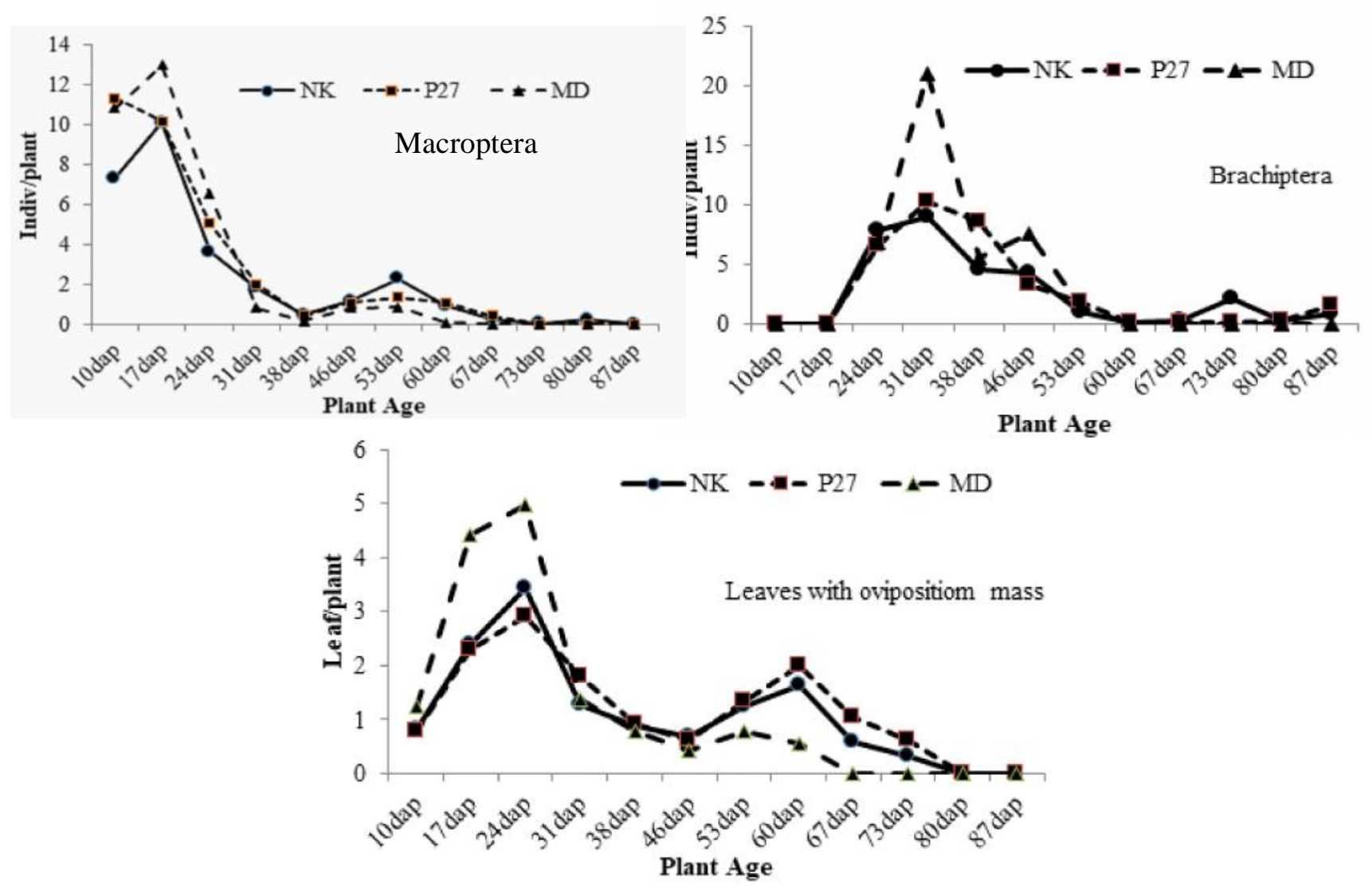

Figure 5. Population density dynamics of winged white-bellied planthoppers (macroptera, brachiptera, and leaves with oviposition mass) on three corn cultivars. 
on cv. Madura tended to be higher than those on cv. P27 and NK. This phenomenon occurred probably because cv. Madura is a local variety that is early maturing (68 days), so that the nutrients contained are faster available to WBP (Arifin \& Fatmawati, 2011). The population density of WBP and the number of leaves with oviposition mass in hybrid corn cv.P-27 and NK tended to be not different (Figure 5).

The natural enemies found included 9 orders from the Insecta class and 1 order from the Arachnida class. Predators found can be grouped into generalist predators and specialist predators (Symondson et al., 2002). This finding is different from Nelly et al. (2017) who reported that WBP's natural enemies consisted of 5 orders including Insecta and Arachnida classes. The report also found no mirid bugs of Miridae family and rove beetles (genus Paederus, family Staphylinidae) which are specialist predators that are very potential as biological control agents for planthoppers, including WBP in corn.

Fluctuations in the population density of specialist and generalist predator were different. The peak of population density of specialist predator, i.e. mirid bugs (Cyrtorhinus) and rove beetles (Paederus), tended to occur when the plants were young in which the WBP population density was also high (Figure 5), while the peak of population density of generalist predator was varied. The population density of lady beetles (Coccinellidae) was high when the WBP population was also high, while the population density of spiders (Araneae) was high when the plants were old (Figure 7 ), in which the population density of WBP was low (Figure 5). This phenomenon is natural because the existence of specialist predators is very dependent on their prey, WBP, while generalist predators are not entirely dependent on WPP. In other words, the density of specialist predator populations is more dependent on the density of the WBP population as opposed to generalist predators.

\section{Natural Enemies Population in the Experimental}

Plots. Natural enemies found include groups of spiders from the Araneae order, Arachnida class and insects. Most of the natural enemies found are predators including the Orthoptera order, Hemiptera, Coleoptera, and Diptera. There was a parasitoid wasps found, namely Xanthopimla from the Ichneumonidae family. By their nature, the predators can be grouped into generalist predators and specialist predators (Sheehan, 1986). Mirid bugs, syrphid flies, net-winged insects, and rove beetles are specialist predators (Nasir et al., 2012; Pappas et al., 2011; Belliure \& Michaud, 2001; Shepard et al., 1995; Reyes \& Gabriel, 1975) who prey on planthoppers and lice from Homoptera sub-order, while others can be categorized as generalist predators (Maramis, 2014; Schenk \& Bacher, 2002; Day et al., 2006; Shepard et al., 1995; Rosenheim et al., 1993) who prey on many types of insects (Table 1).

The population density of specialist natural enemies, namely mirid bugs and rove beetles that feed on lice eggs also fluctuated like that of WBP following the age of corn plants. At 10 dap, the population density of these two predators was still low, then increased as the plant aged. Rove beetles population increased faster and reached its peak population density at $31 \mathrm{dap}$, while the mirid bugs population reached the peak population density at 35 and 50 dap. The population density of rove beetles on cv. Madura reaching 2 individuals per plant was higher than on cv.P-27 and NK which only reached 1 individual per plant. The fluctuations pattern in mirid bugs and rove beetles population density among corn cultivars tends to be different. The peak population density of mirid bugs on cv. Madura and P-27 occurred

Table 1. Natural enemies found in the corn fields observed

\begin{tabular}{clllll}
\hline No. & Order & Family & Genus & Common name & Characteristic \\
\hline 1 & Orthoptera & Mantidae & $?$ & Mantises & Generalist \\
2 & Coleoptera & Coccinellidae & Coccinella & Lady beetles & Generalist \\
3 & Hemiptera & Miridae & Cyrtorhinus & Mirid bugs & Specialist \\
4 & Orthoptera & Tettigonidae & $?$ & Predatory cricket & Generalist \\
5 & Diptera & Syrphidae & $?$ & Syrphid flies & Specialist \\
6 & Neuroptera & Chrysopidae & Chrysopa & Net-winged insects & Specialist \\
7 & Coleoptera & Carabidae & Ophionea & Ground beetles & Generalist \\
8 & Hymenoptera & Ichneumonidae & Xanthopimpla & Parasitoid wasps & - \\
9 & Coleoptera & Staphylinidae & Paederus & Rove beetles & Specialist \\
10 & Araneae & & & Spiders & Generalist \\
\hline
\end{tabular}


at 31 dap, while on cv. NK it occurred at 50 dap (Figure 6 ). The population density of rove beetles on cv. P-27 was high and it reached its peak at 31 dap, while on cv. NK the peak of predator population density was reached at 38 dap. The peak of the rove beetles population density on cv. Madura occurred at 31 and 46 dap (Figure 6).

The fluctuations pattern in population density of generalist predators such as spiders and lady beetles is somewhat different. When the plants were young, 10 60 dap, the population density of spiders was still low and it started to rise and reached the peak of population density at 70-87 dap. In contrast, the population density of lady beetles was high at 31 dap, and then kept decreasing since 45-87 dap. The fluctuations patterns in population density of spiders and lady beetles on the three corn cultivars were observed similar, except for early maturing Madura variety. On cv. Madura, the population density of spiders was low since 60 dap, meanwhile on cv. P-27 and NK, the population density of spiders began to rise. This is because at 60 days after planting, cv. Madura was ready to be harvested. Population density of lady beetles on cv. Madura began to be low since 53 days after planting, although this predator population density also decreased on $\mathrm{cv}$. P-27 and NK (Figure 7).

\section{CONCLUSION}

Some conclusions can be drawn from the results of this study are as follows:

Growth pattern of population density of WBP adult stage of macroptera, number of leaves with oviposition mass and density of nymphs and adult brachiptera stage on all corn cultivars were in line with the plant growth. During plant growth, two population peaks were found. The peak of population density of BWP adult stage of macroptera occurred at 17 and 53 days after planting, the highest number of leaves with oviposition mass was observed at 24 and 65 days after planting, and the peak
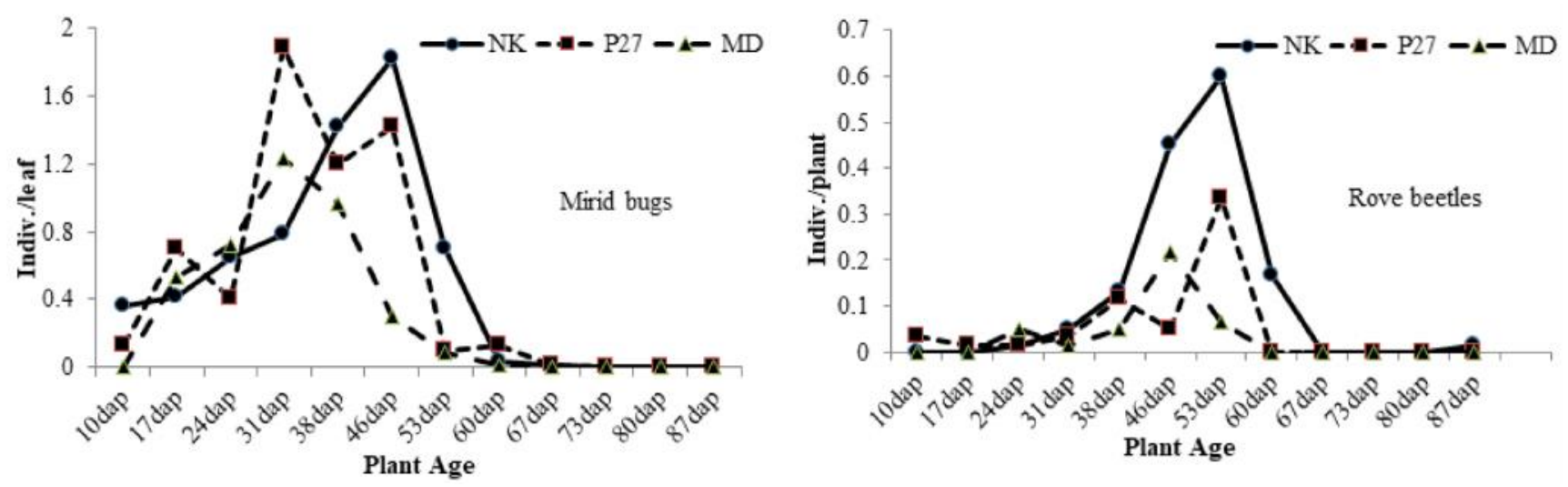

Figure 6. Population dynamics of specialist predators of mirid bugs and rove beetles on corn plants cv. Madura, P27 and NK.
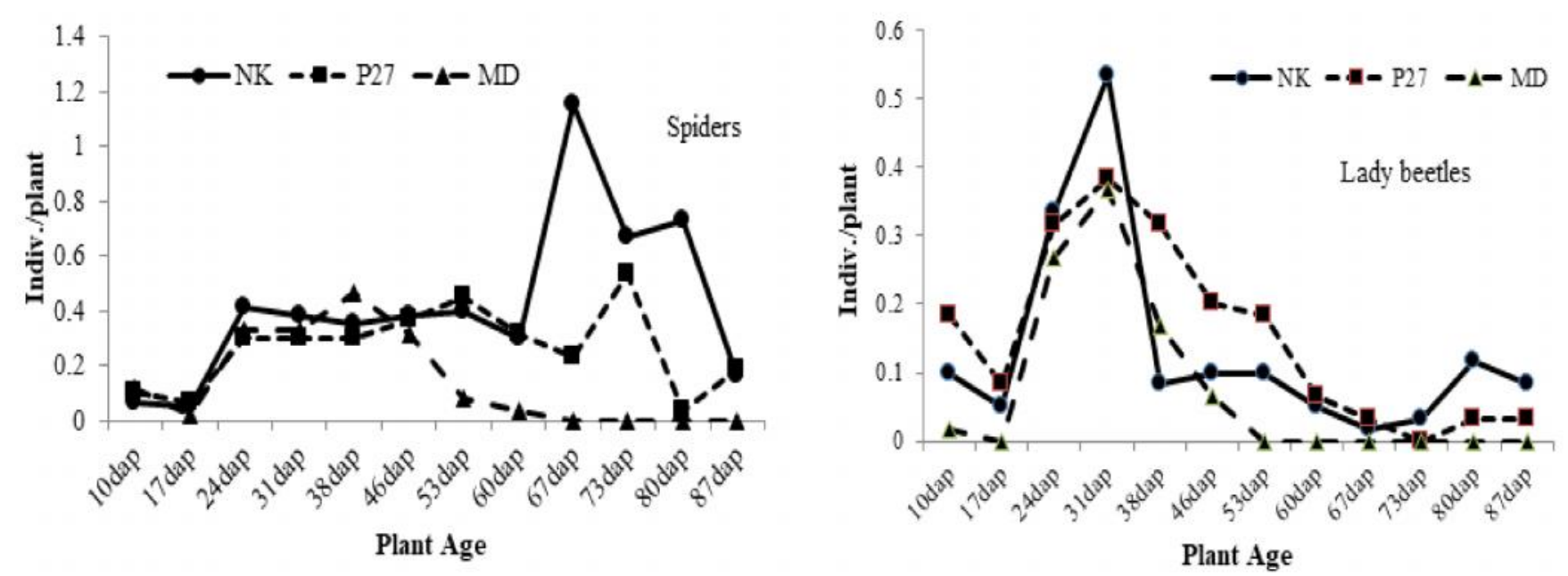

Figure 7. Population dynamics of of spiders and lady beetles on corn plants cv. Madura, P-27 and NK. 
of population density of BWP stage of nymph and adult brachiptera occurred at 31 and 75 days after planting.

Natural enemies found consisted of 9 orders including specialist predators of mirid bugs (Cyrtorhinus), rove beetles (Paederus), syrphid flies (Syrphidae), netwinged insects (Chrysopa) and generalist predators of spiders (Araneae), lady beetles (Coccinellidae), mantises (Mantidae), ground beetles (Ophionea), and predatory crickets (Tettigonidae). The population of specialist predators was dynamic following the WBP population, while the dynamics of generalist predator population was varied.

\section{ACKNOWLEDGMENTS}

This research is a Leading Research of University of Lampung funded by DIPA BLU Universitas Lampung in 2017 with Letter of Assignment No. 808/ UN26.21/PP/2017. On this occasion the authors would like to thank the Chair of the Research and Community Service (LP2M) of Univesitas Lampung who have funded this research.

\section{REFERENCES}

Alagar M, Suresh R, Samiyappan R, \& Saravanakumar, D. 2007. Reaction of resistant and susceptible rice genotypes against brown planthopper (Nilaparvata lugens). Phytoparasitica 35(4): 346-356.

Arifin Z \& Fatmawati. 2011. Pemurnian dan pengembangan jagung varietas madding, talango dan guluk di Kabupaten Sumenep. Prosiding Seminar Nasional Serealia, Maros, Oktober 3-4, 2011. pp. 103-112.

Beers EH, Mills NJ, Shearer PW, Horton DR, Milickzy ER, Amarasekare KG, \& Gontijo LM. 2016. Nontarget effects of orchard pesticides on natural enemies: Lessons from the field and laboratory. Biol. Contr. 102: 44-52.

Belliure B \& Michaud JP. 2001. Biology and behavior of Pseudodorus clavatus (Diptera: Syrphidae), an important predator of citrus aphids. Ann. Entomol. Soc. Am. 94(1): 91-96.

Day KR, Docherty M, Leather SR, \& Kidd NAC. 2006. The role of generalist insect predators and pathogens in suppressing green spruce aphid population through direct mortality and mediation of aphid dropping behavior. Biol. Contr. 38(2): 233-246. de Oliveira CM, de Oliveira E, Regina I, de Sousa IRP, Alves E, Dolesal W, Paradell S, Lenicov AMMDR, \& Frizzas MR. 2013. Abundance and species richness of leafhopper and planthopper (Hemiptera: Cicadellidae and Delphacidae) in Brazilian maize crops. Fla. Entomol. 96(4): 1470-1481.

Dupo ALB \& Barrion AT. 2009. Taxonomy and general biology of delphacid planthoppers in rice agroecosystem. In: Heong KL \& Hardy B. (eds.) Planthopper: New threats to the sustainability of intensive rice production systems in Asia. International Rice Research Institute. Los Banos, Philippines.

Dyck VA, Misra BC, Alam S, Chen CN, Hsieh CY, \& Rejesus RS. 1979. Ecology of the brown planthopper in the tropics. In: IRRI (ed), Brown planthopper: Threat to Rice Production in Asia. pp. 61-100.

Kalshoven LGE. 1981. The Pests of Crops in Indonesia. Revised by Van der Laan. PT Ichtiar Baru-Van Hoeve, Jakarta.

Maramis RTD. 2014. Diversitas laba-laba (Predator Generalis) pada tanaman kacang merah (Vigna angularis) di Kecamatan Tompaso, Kabupaten Minahasa. Jurnal Bioslogos 4(1): 33-40.

Nasir S, Akram W, \& Ahmed F. 2012. The population dynamics, ecological and seasonal activity of Paederus fuscipes Curtis (Staphylinidae; Coleoptera) in the Punjab, Pakistan. APCBEE Procedia 4: 36-41.

Naulth LR \& Amar ED. 1989. Leafhopper and planthopper transmission of plant viruses. Ann. Rev. Entomol. 34: 503-529.

Nelly N, Syahrawati M, \& Hamid H. 2017. Abundance of corn planthopper (Stenocranus pacificus) (Hemiptera: Delphacidae) and the potential natural enemies in West Sumatera Indonesia. Biodiversitas 18(2): 697-700.

Nicholls CI \& Altieri MA. 2007. Agroecology: contributions towards a renewed ecological foundation for pest management. In: Kogan $\mathrm{H}$ \& Jepson AP. Perspectives in Ecological Theory and Integrated Pest Management. Cambridge University Press, pp. 431-468. 
Pappas ML, Broufas GD, \& Koveos DS. 2011. Chrysopid predators and their role in biological control. J. Entomol. 8(3): 301-326.

Reyes TM \& Gabriel BP. 1975. The life history and consumption habits of Cyrtorhinus lividipennis Reuter (Hemiptera: Miridae). Philipp. Ent. 3(2): 79-88.

Rosenheim JA, Wilhoit LR, \& Armer CA. 1993. Influence of intraguild predation among generalist insect predators on the suppression of an herbivore population. Oecologia 96: 439-449.

Schenk D \& Bacher S. 2002. Functional response of a generalist insect predator to one of its prey species in the field. J. Anim. Ecol. 71(3): 524-531.

Sheehan W. 1986. Response by specialist and generalist natural enemies to agroecosystem diversification: a selective review. Environ. Entomol. 15(3): 456461.

Shepard BM, Barrion AT, \& Litsinger JA. 1995. Mitra petani padi: serangga, laba-laba dan pathogen yang membantu. Program Nasional Pengendalian Hama Terpadu. Departemen Partanian, Jakarta.

Staley JT, Stewart-Jones A, Pope TW, Wright DJ, Leather SR, Hadley P, Rossiter JT, van Emden HF, \& Poppy GM. 2010. Veriying responses of insect herbivores to altered plant chemistry under organic and conventional treatments. Proc. $R$. Soc. B 277: 779-786.

Symondson WOC, Sunderland KD, \& Greenstone MH. 2002. Can generalist predators be effective biocontrol agents?. Annu. Rev. Entomol.47: 561594.
Surtikanti. 2011. Hama dan penyakit penting tanaman jagung dan pengendaliannya. Prosiding Seminar Nasional Serealia. Maros, Oktober 3-4, 2011. Pp. 497-508.

Susilo FX, Swibawa IG, Indriyati, Hariri AM, Purnomo, Hasibuan R, Wibowo L, Suharjo R, Fitriana Y, Dirmawati SR, Solikhin, Sumardiyono, Rwandini RA, Sembodo DRY, \& Suputa. 2017. The whitebellied planthopper (Hemiptera: Delphacidae) infesting corn plants in South Lampung, Indonesia. J. HPT Tropika 17(1): 96-103.

Syobu S, Mikuriya H, Yamaguchi J, Matsuzaki M, \& Matsumura M. 2002. Fluctuations and Factors Affecting the Wing-Form Ratio of the Brown Planthopper, Nilaparvata lugens Stål in Rice Fields. Jpn. J. Appl. Entomol. Zool. 46(3): 135143.

Untung K. 2001. Pengantar Pengelolaan Hama Terpadu. Gadjah Mada University Press. Yogyakarta.

Visarto P, Zalucki MP, Nesbitt HJ, \& Jahn GC. 2001. Effect of fertilizer, pesticide treatment, and plant variety on the realized fecundity and survival rates of brown planthopper, Nilaparvata lugens (Stål) (Homoptera: Delphacidae)-Generating outbreaks in Cambodia. J. Asia-Pacific Entomol. 4(1): 7584. 